International Journal of Trend in Scientific Research and Development (IJTSRD)

Volume: 3 | Issue: 2 | Jan-Feb 2019 Available Online: www.ijtsrd.com e-ISSN: 2456 - 6470

\title{
Analysis of Accounting Standards: IFRS \& IND AS
}

\author{
Rishi Agarwal1, Dr. R. K. Agarwal² \\ ${ }^{1}$ Research Scholar, ${ }^{2}$ Associate Professor \\ Department of Accountancy and Business Statistics, University of Rajasthan, Jaipur, Rajasthan, India
}

Indian Accounting Standards: A brief

1. Meaning:- Indian Accounting Standards (abbreviated as Ind AS) are a set of accounting standards notified by the Ministry of Corporate Affairs which are converged with International Financial Reporting Standards (IFRS) (IND AS is notified by NACAS on $25^{\text {th }}$ Feb 2011.) (NFRA= National Financial Reporting Authority U/s 132)

2. Applicability of IND AS: - The Ind AS shall be applicable to the companies as follows: As notified by MCA as on 16/02/15 in Companies (Indian Accounting Standards) Rules, 2015.

Obligation to comply with Indian Accounting Standards (Ind AS). - (1) The Companies and their auditors shall comply with the Indian Accounting Standards (Ind AS) specified in Annexure to these rules in preparation of their financial statements and audit respectively, in the following manner.

\begin{tabular}{|c|c|c|}
\hline & \multicolumn{2}{|c|}{ On mandatory basis } \\
\hline (i) On voluntary basis & $\begin{array}{l}\text { (ii) Accounting periods beginning on } \\
\text { or after } 1 / 4 / 16(\text { For } 31 / 3 / 17) \\
\text { with the comparatives. }\end{array}$ & $\begin{array}{c}\text { (iii) Accounting periods } \\
\text { beginning on or after } \\
\text { 01/04/17(For } 31 / 3 / 18 \text { ), with } \\
\text { the comparatives. }\end{array}$ \\
\hline $\begin{array}{l}\text { Accounting periods beginning } \\
\text { on or after April } 1,2015 \text {, with } \\
\text { the comparatives for the } \\
\text { periods ending } 31^{\text {st }} \text { March, } 2015 \\
\text { or thereafter; }\end{array}$ & $\begin{array}{l}\text { A. Companies whose equity and/or debt } \\
\text { securities are listed or are in the } \\
\text { process of listing on any stock } \\
\text { exchange in India or outside India and } \\
\text { having net worth* of Rs. } 500 \text { Crore or } \\
\text { more. International Journal } \\
\text { B. Companies other than those covered in } \\
\text { (ii) (a) above, having net worth of Rs. } \\
\text { C00 Crore or more. } \\
\text { C. Holding, subsidiary, joint venture or } \\
\text { associate Above. }\end{array}$ & $\begin{array}{l}\text { A. Companies whose equity and/or } \\
\text { debt securities are listed or are } \\
\text { in the process of being listed on } \\
\text { any stock exchange in India or } \\
\text { outside India. } \\
\text { B. Unlisted companies having net } \\
\text { worth of } 250 \text { Crore or more but } \\
\text { less than rupees } 500 \text { Crore. } \\
\text { C. Holding, subsidiary, joint } \\
\text { venture or associate companies } \\
\text { of above. }\end{array}$ \\
\hline
\end{tabular}

*NET WORTH: "NET WORTH" shall have the meaning assigned to it in clause (57) of section 2 of the Act

"NET WORTH" means the aggregate value of the paid-up share capital and all reserves created out of the profits and securities premium account, after deducting the aggregate value of the accumulated losses, deferred expenditure and miscellaneous expenditure not written off, as per the audited balance sheet, but does not include reserves created out of revaluation of assets, write-back of depreciation and amalgamation.

Note:-

1. Companies listed on SME exchanges shall not be required to apply Ind AS.

2. Once Ind AS is followed by the company, it shall be required to follow, for all the subsequent financial statements.

3. This press realise do not apply on Banking Companies, Insurance Companies and NBFC's 
International Journal of Trend in Scientific Research and Development (IJTSRD) @ www.ijtsrd.com eISSN: 2456-6470

\section{IND AS ROADMAP FOR BANKS, INSURANCE COMPANIES AND NBFCS}

A. Scheduled commercial banks (excluding RRBs) and insurers/insurance companies:- Mandatory for accounting periods beginning from 1 April 2018 onwards (With Comparative)

1. Scheduled commercial banks (excluding RRBs), Insurers/insurance companies

2. Holding, subsidiary, joint venture or associate companies of scheduled commercial banks

B. NBFCs: NBFCs will be required to prepare Ind AS based financial statements in two phases.

Phase 1: Mandatory for accounting periods beginning from 1 April 2018 onwards (With Comparative)

1. NBFCs (Whether listed or unlisted) having a net worth of Rs. 500 crore or more

2. Holding, subsidiary, joint venture or associate companies of the above, other than those companies already covered under the corporate roadmap announced byMCA

*On insurance Company:- Applicable from 01st April 2020(20-21) as notified as on 28/6/17 by IRDA

Phase 2:Mandatory for accounting periods beginning from 1 April 2019 onwards (With Comparative)

1. NBFCs whose equity and/or debt securities are listed or are in the process of listing on any stock exchange.

2. NBFCs that are unlisted companies, having a net worth of 250 crore INR or more but less than 500 Crore INR

3. Holding, subsidiary, joint venture or associate companies of companies covered above, other than those companies already covered under the corporate roadmap announced by MCA

Voluntary adoption not permitted to BANKS, INSURANCE COMPANIES AND NBFCS

D. Companies/entities not covered in the roadmap

1. NBFCs having a net worth below 250 crore INR.

2. Urban cooperative banks (UCBs) and RRBs.

\section{NUMBER AND NAME OF IND AS, WITH RESPECTIVE IFRS OR IAS}

\begin{tabular}{|c|c|c|c|}
\hline S. N. & Name of Ind AS with Number & IFRS & IAS \\
\hline 1. & Ind AS 101 First-time Adoption of Indian Accounting Standards & 1 & \\
\hline 2. & Ind AS 102 Share based Payment in SCletrth/fich & 2 & \\
\hline 3. & Ind AS 103 Business Combinations & 3 & \\
\hline 4. & Ind AS 104 Insurance Contracts & 4 & \\
\hline 5. & Ind AS 105 Non current Assets Held for Sale and Discontinued Operations & 5 & \\
\hline 6. & Ind AS 106 Exploration for and Evaluation of Mineral Resources & 6 & \\
\hline 7. & Ind AS 107 Financial Instruments: Disclosures al Journall & 7 & \\
\hline 8. & Ind AS 108 Operating Segments of Trend in Scientific & 8 & \\
\hline 9. & Ind AS 109 Financial Instruments: Recognition and Measurement issued. & 9 & \\
\hline 10. & Ind AS 110 Consolidated Financial. & 10 & \\
\hline 11. & Ind AS 111 Joint Arrangements. & 11 & \\
\hline 12. & Ind AS 112 Disclosure of Interest in Other. & 12 & \\
\hline 13. & Ind AS 113 Fair Value Measurement. & 13 & \\
\hline 14. & Ind AS 114 Regulatory Deferral Accounts. & 14 & \\
\hline 15. & Ind AS 1 Presentation of Financial Statements & & 1 \\
\hline 16. & Ind AS 2 Inventories & & 2 \\
\hline 17. & Ind AS 7 Statement of Cash Flows & & 7 \\
\hline 18. & Ind AS 8 Accounting Policies, Changes in Accounting Estimates and Errors & & 8 \\
\hline 19. & Ind AS 10 Events after the Reporting Period & & 10 \\
\hline 20. & Ind AS 11 Construction Contracts * & & 11 \\
\hline 21. & Ind AS 12 Income Taxes & & 12 \\
\hline 22. & Ind AS 16 Property, Plant and Equipment & & 16 \\
\hline 23. & Ind AS 17 Leases & & 17 \\
\hline 24. & Ind AS 18 Revenue* & & 18 \\
\hline 25. & Ind AS 19 Employee Benefits & & 19 \\
\hline 26. & Ind AS 20 Accounting for Government Grants and Disclosure of Government Assistance & & 20 \\
\hline 27. & Ind AS 21 The Effects of Changes in Foreign Exchange Rates & & 21 \\
\hline 28. & Ind AS 23 Borrowing Costs & & 23 \\
\hline 29. & Ind AS 24 Related Party Disclosures & & 24 \\
\hline 30. & Ind AS 27 Consolidated and Separate Financial Statements & & 27 \\
\hline 31. & Ind AS 28 Investments in Associates & & 28 \\
\hline 32. & Ind AS 29 Financial Reporting in Hyperinflationary Economies & & 29 \\
\hline 33. & Ind AS 32 Financial Instruments: Presentation & & 32 \\
\hline 34. & Ind AS 33 Earnings per Share & & 33 \\
\hline 35. & Ind AS 34 Interim Financial Reporting & & 34 \\
\hline 36. & Ind AS 36 Impairment of Assets & & 36 \\
\hline 37. & Ind AS 37 Provisions, Contingent Liabilities and Contingent Assets & & 37 \\
\hline 38. & Ind AS 38 Intangible Assets & & 38 \\
\hline 39. & Ind AS 40 Investment Property & & 40 \\
\hline 40. & Ind AS 41 Agriculture. & & 41 \\
\hline
\end{tabular}


International Journal of Trend in Scientific Research and Development (IJTSRD) @ www.ijtsrd.com eISSN: 2456-6470

AS 1: Presentation of Financial Statements

PART I: Differences between IND AS and Existing AS

\begin{tabular}{|c|c|c|c|}
\hline SN & Basis of Differences & IND AS 1: Presentation of Financial Statements & $\begin{array}{l}\text { AS 1: Disclosure of } \\
\text { Accounting Policy }\end{array}$ \\
\hline 1 & Scope & $\begin{array}{l}\text { Deals in presentation of Financial Statements (FS). } \\
\text { (Wider scope) }\end{array}$ & $\begin{array}{l}\text { Deals with Disclosure of } \\
\text { Accounting Policy (Limited } \\
\text { Scope) }\end{array}$ \\
\hline 2 & $\begin{array}{l}\text { Explicit Statement of } \\
\text { Compliance }\end{array}$ & $\begin{array}{l}\text { Ind AS are complied in the FS. Ind AS } 1 \text { allows } \\
\text { deviation from a requirement of an IND AS in case the } \\
\text { management concludes that compliance with Ind ASs } \\
\text { will be misleading and if the regulatory framework } \\
\text { requires does not prohibit such a departure. }\end{array}$ & No Such Provision \\
\hline 3 & $\begin{array}{l}\text { Current and Non- } \\
\text { current Classification }\end{array}$ & Explained & Not explained \\
\hline 4 & Extraordinary Items & $\begin{array}{l}\text { Prohibits presentation of any item as Extraordinary } \\
\text { Item }\end{array}$ & $\begin{array}{l}\text { Permits presentation of any } \\
\text { item as Extraordinary Item }\end{array}$ \\
\hline 5 & $\begin{array}{l}\text { Disclosure of } \\
\text { Judgements and } \\
\text { Assumptions made }\end{array}$ & Required & No such disclosure explicit. \\
\hline 6 & $\begin{array}{l}\text { Classification of } \\
\text { Expenses }\end{array}$ & Presented based on nature of expenses & No Such Provision \\
\hline 7 & $\begin{array}{l}\text { Presentation of Balance } \\
\text { Sheet at the beginning } \\
\text { of the earliest period }\end{array}$ & $\begin{array}{l}\text { Ind AS } 1 \text { requires, when } \\
\text { (a) Applies an accounting policy retrospectively or } \\
\text { (b) makes a retrospective restatement of items in the } \\
\text { financial statements, or } \\
\text { (c) when it reclassifies items in its financial statements. }\end{array}$ & Not Required \\
\hline 8 & $\begin{array}{l}\text { Disclosure of } \\
\text { Reclassified of Items } \\
\text { with reason. }\end{array}$ & Not Required & Required \\
\hline 9 & $\begin{array}{l}\text { Statement of Changes in } \\
\text { Equity }\end{array}$ & Required IU International. Iournal & Not Required \\
\hline 10 & $\begin{array}{l}\text { Statement of Other } \\
\text { Comprehensive Income } \\
\text { in two sections }\end{array}$ & $\begin{array}{cc}\text { Required } & \text { of Trend in Scientific } \\
\text { Research and } & \end{array}$ & Not Required \\
\hline 11 & $\begin{array}{l}\text { Inclusion of } \\
\text { Comparative } \\
\text { Information }\end{array}$ & $\begin{array}{l}\text { Dequired } \% \text { Development } \\
\text { RSN:2456-6470 }\end{array}$ & Not Required \\
\hline 12 & $\begin{array}{l}\text { Classification of Long- } \\
\text { term Loan Arrangement }\end{array}$ & $\begin{array}{l}\text { Long term loan arrangement need not be classified as } \\
\text { current on account of breach of a material provision, } \\
\text { for which the lender has agreed to waive before the } \\
\text { approval of financial statements. }\end{array}$ & No Such Provision \\
\hline
\end{tabular}

Ind AS 2: Valuation of Inventory

\begin{tabular}{|c|l|l|l|}
\hline SN & Basis of Differences & \multicolumn{1}{|c|}{ Ind AS 2: Valuation of Inventory } & \multicolumn{1}{|c|}{ AS 2: Valuation of Inventory } \\
\hline 1. & $\begin{array}{l}\text { Subsequent } \\
\text { Recognition }\end{array}$ & $\begin{array}{l}\text { Subsequent recognition of cost/carrying } \\
\text { amount of inventories as an expense. }\end{array}$ & Does not provide the same \\
\hline 2 & $\begin{array}{l}\text { Inventory Provider } \\
\text { of Service }\end{array}$ & $\begin{array}{l}\text { Explanation with regard to inventories of } \\
\text { service providers }\end{array}$ & Does not Contain such an explanation. \\
\hline 4 & $\begin{array}{l}\text { Machinery Spares } \\
\text { Commodity Broker- } \\
\text { traders }\end{array}$ & $\begin{array}{l}\text { Mespect of such spares as this aspect is } \\
\text { covered under Ind AS 16. } \\
\text { less costs to sell. }\end{array}$ & $\begin{array}{l}\text { The existing AS 2 explains that inventories } \\
\text { do not include spare parts, servicing } \\
\text { equipment and standby equipment which } \\
\text { meet the definition of PPE as per AS 10. } \\
\text { Such items are accounted for in accordance } \\
\text { with AS 10. }\end{array}$ \\
\hline 5 & $\begin{array}{l}\text { Definition of Fair Value } \\
\text { and Distinction } \\
\text { Between NRV and Fair } \\
\text { Value }\end{array}$ & $\begin{array}{l}\text { Explanation in respect of distinction } \\
\text { between net realisable value and fair } \\
\text { value. }\end{array}$ & $\begin{array}{l}\text { This aspect is not in AS 2. } \\
\text { and such explanation. }\end{array}$ \\
\hline 6 & $\begin{array}{l}\text { Subsequent } \\
\text { Assessment of NRV }\end{array}$ & $\begin{array}{l}\text { Provides detailed guidance in case of } \\
\text { subsequent assessment of NRV. It also } \\
\text { deals with the reversal of the write-down } \\
\text { of inventories to NRV to the extent of the }\end{array}$ & Does not deal with such reversal. \\
\hline
\end{tabular}


International Journal of Trend in Scientific Research and Development (IJTSRD) @ www.ijtsrd.com eISSN: 2456-6470

\begin{tabular}{|c|c|c|c|}
\hline & & $\begin{array}{l}\text { amount of original write-down, \& the } \\
\text { recognition and disclosure thereof in the } \\
\text { financial statements. }\end{array}$ & \\
\hline 7 & $\begin{array}{l}\text { Inventories Acquired } \\
\text { on Deferred } \\
\text { Settlement Terms }\end{array}$ & $\begin{array}{l}\text { A difference between the purchase price } \\
\text { for normal } \\
\text { credit terms and the amount paid, is } \\
\text { recognised as interest expense }\end{array}$ & No such treatment. \\
\hline 8 & Cost Formula & $\begin{array}{l}\text { Requires the use of consistent cost } \\
\text { formula in determining the cost of an } \\
\text { item of inventory. }\end{array}$ & $\begin{array}{l}\text { Does not specifically requires the use of } \\
\text { consistent cost formulas }\end{array}$ \\
\hline
\end{tabular}

Ind AS 7: Cash Flow Statement

\begin{tabular}{|c|c|c|c|}
\hline SN & Basis of Differences & Ind AS 7: Cash Flow Statement & AS 3: Cash Flow Statement \\
\hline 1. & $\begin{array}{l}\text { Bank Overdraft Repayable } \\
\text { on Demand }\end{array}$ & $\begin{array}{l}\text { Bank overdrafts which are repayable on } \\
\text { demand as a part of cash and cash equivalents }\end{array}$ & No Such provision \\
\hline 2 & $\begin{array}{l}\text { Adjustment of the Profit or } \\
\text { Loss for the Effects of } \\
\text { Undistributed Profits of } \\
\text { Associates and Non- } \\
\text { controlling Interests }\end{array}$ & $\begin{array}{l}\text { Requires such adjustment under Indirect } \\
\text { Method }\end{array}$ & No such provision \\
\hline 3 & $\begin{array}{l}\text { Cash Flows associated with } \\
\text { Extraordinary Activities }\end{array}$ & $\begin{array}{l}\text { No items are classified as Extraordinary } \\
\text { Activities. }\end{array}$ & $\begin{array}{l}\text { Extraordinary activities to be } \\
\text { separately classified as arising from } \\
\text { operating, investing and financing } \\
\text { activities }\end{array}$ \\
\hline 4 & $\begin{array}{l}\text { Disclosure of Cash and Cash } \\
\text { Equivalents in Specific } \\
\text { Situations }\end{array}$ & $\begin{array}{l}\text { Disclose the amount of cash \& cash equivalents } \\
\text { and other assets \& liabilities in the subsidiaries } \\
\text { or other businesses over which control is } \\
\text { obtained or lost }\end{array}$ & No such provision \\
\hline 5 & $\begin{array}{l}\text { New Examples of Cash Flows } \\
\text { arising from Financing } \\
\text { Activities }\end{array}$ & $\begin{array}{l}\text { cash payments to owners to acquire or } \\
\text { redeem the entity's shares } \\
\text { cash proceeds from mortgages nal } \\
\text { cash payments by a lessee for the reduction } \\
\text { of the outstanding liability relating to a } \\
\text { finance lease. Research and }\end{array}$ & Not included \\
\hline 6 & $\begin{array}{l}\text { Investment in Subsidiaries, } \\
\text { Associates and JVs } \\
\text { (Investees) }\end{array}$ & $\begin{array}{l}\text { Mentions the use of equity or cost method } \\
\text { Specifically deals by using equity method }\end{array}$ & Not contain such requirements. \\
\hline 7 & $\begin{array}{l}\text { Use of Different Terminology } \\
\text { and Translation of Cash } \\
\text { Flows of a Foreign } \\
\text { Subsidiary. }\end{array}$ & Functi & Reporting currency \\
\hline 8 & Disclosures & Requires more disclosures & No disclosures. \\
\hline
\end{tabular}

Ind AS 8: Accounting Policies, Changes in Accounting Estimates and Errors

\begin{tabular}{|c|l|l|l|}
\hline SN & Basis of Differences & $\begin{array}{r}\text { IND AS 8: (Accounting Policies, } \\
\text { Changes in Accounting Estimates } \\
\text { and Errors) }\end{array}$ & $\begin{array}{r}\text { AS } 5 \text { (Net Profit or Loss for the } \\
\text { Period, Prior Period Items and } \\
\text { Changes in Accounting } \\
\text { Policies (Revised)) }\end{array}$ \\
\hline 1 & Objective & $\begin{array}{l}\text { Prescribe the criteria for selecting and } \\
\text { changing accounting policies, together } \\
\text { with the accounting treatment and } \\
\text { disclosure of changes in accounting } \\
\text { policies, changes in accounting estimates } \\
\text { and corrections of errors }\end{array}$ & $\begin{array}{l}\text { Prescribe the classification and } \\
\text { disclosure of certain items in the } \\
\text { statement of profit and loss. }\end{array}$ \\
\hline 2 & Basis & $\begin{array}{l}\text { Intends to enhance the relevance and } \\
\text { reliability of an entity's financial } \\
\text { statements and the comparability of } \\
\text { those financial statements over time and } \\
\text { with the financial statements of other } \\
\text { entities }\end{array}$ & $\begin{array}{l}\text { Classification and disclosure of certain } \\
\text { items in the statement of profit and loss } \\
\text { for uniform preparation and presentation } \\
\text { of financial statements }\end{array}$ \\
\hline 3 & $\begin{array}{l}\text { Presentations of } \\
\text { Extraordinary Items }\end{array}$ & Prohibits & Provide \\
\hline
\end{tabular}


International Journal of Trend in Scientific Research and Development (IJTSRD) @ www.ijtsrd.com eISSN: 2456-6470

\begin{tabular}{|c|c|c|c|}
\hline 4 & $\begin{array}{l}\text { Definition of Accounting } \\
\text { Policies }\end{array}$ & $\begin{array}{l}\text { Broadens the definition to include bases, } \\
\text { conventions, rules and practices (in } \\
\text { addition to principles) applied by an } \\
\text { entity in the preparation and } \\
\text { presentation of } \\
\text { Financial statements. }\end{array}$ & $\begin{array}{l}\text { Restricts the definition to the specific } \\
\text { accounting principles \& the methods of } \\
\text { applying those } \\
\text { principles }\end{array}$ \\
\hline 5 & $\begin{array}{l}\text { Change in Accounting } \\
\text { Policies if required by } \\
\text { statute }\end{array}$ & Not included. & Included. \\
\hline 6 & $\begin{array}{l}\text { Retrospective Accounting } \\
\text { of Changes in Accounting } \\
\text { Policies }\end{array}$ & $\begin{array}{l}\text { Requires that changes in accounting } \\
\text { policies should be accounted for with } \\
\text { retrospective effect. }\end{array}$ & $\begin{array}{l}\text { Not specify how change in } \\
\text { accounting policy should be accounted } \\
\text { for. }\end{array}$ \\
\hline 7 & $\begin{array}{l}\text { Rectification of Material } \\
\text { Prior Period Errors }\end{array}$ & $\begin{array}{l}\text { Rectification of material prior period } \\
\text { errors with retrospective effect except } \\
\text { where it is impracticable to determine } \\
\text { the period specific effects. }\end{array}$ & Prospective effect \\
\hline
\end{tabular}

Ind AS 10: Events after the Reporting Period.

\begin{tabular}{|c|c|c|c|c|}
\hline$\underline{\text { SN }}$ & \multicolumn{2}{|l|}{ Basis of Differences } & $\begin{array}{l}\text { IND AS 10: Events after the Reporting } \\
\text { Period. }\end{array}$ & $\begin{array}{c}\text { Amended AS4: Contingencies } \\
\text { and EOABS Date }\end{array}$ \\
\hline 1 & \multicolumn{2}{|l|}{$\begin{array}{l}\text { Non Adjusting Events if } \\
\text { Material }\end{array}$} & $\begin{array}{l}\text { Disclosed in the financial statements } \\
\text { (Disclosed in notes to account.) }\end{array}$ & $\begin{array}{l}\text { Disclosed in the approving } \\
\text { authority. Report of }\end{array}$ \\
\hline 2 & \multicolumn{2}{|l|}{ Proposed Dividend } & $\begin{array}{l}\text { Dividend proposed or declared after the } \\
\text { reporting Period cannot be recognised as a } \\
\text { liability. Disclosed in notes to account. }\end{array}$ & Now Same. \\
\hline 3 & \multicolumn{2}{|c|}{$\begin{array}{l}\text { Distribution of non-cash assets } \\
\text { to owners }\end{array}$} & Guideline Given. & No Guidelines. \\
\hline 4 & \multicolumn{2}{|c|}{$\begin{array}{l}\text { Impact of non-adjusting } \\
\text { event in case of a question } \\
\text { mark on going concern. }\end{array}$} & $\begin{array}{l}\text { Basis of accounting changes from going } \\
\text { concern to liquidation. }\end{array}$ & No Such Requirement. \\
\hline 5 & \multicolumn{2}{|c|}{$\begin{array}{l}\text { In case of breach of a material } \\
\text { provision of a long term loan } \\
\text { arrangement }\end{array}$} & $\begin{array}{l}\text { Considered as an adjusting event (Referred } \\
\text { IND AS 1) Trend in Scientific }\end{array}$ & No Such Provisions. \\
\hline \multirow{2}{*}{\multicolumn{4}{|c|}{$\begin{array}{l}\text { Ind AS 11: Construction Contracts } \\
\begin{array}{|c|c|}\text { SN } & \text { Basis of Differences } \\
\end{array}\end{array}$}} & 8 \\
\hline & & & & AS 7: Constructions Contracts \\
\hline 1 & Fair Value & $\begin{array}{l}\text { Con } \\
\text { of } \mathrm{c}\end{array}$ & $\begin{array}{l}\text { tract revenue shall be measured at fair value } \\
\text { onsideration received/receivable }\end{array}$ & $\begin{array}{l}\text { Does not recognise fair value } \\
\text { concept }\end{array}$ \\
\hline 2 & $\begin{array}{l}\text { Inclusion of Borrowing } \\
\text { costs }\end{array}$ & $\begin{array}{l}\text { Ind } \\
\text { to I }\end{array}$ & $\begin{array}{l}\text { AS } 11 \text { does not specifically make reference } \\
\text { nd AS } 23 .\end{array}$ & $\begin{array}{l}\text { Includes borrowing costs as per AS } \\
16,\end{array}$ \\
\hline 3 & $\begin{array}{l}\text { Accounting for Service } \\
\text { Concession } \\
\text { arrangements }\end{array}$ & $\begin{array}{l}\text { App } \\
\text { asp } \\
\text { App } \\
\text { arr }\end{array}$ & $\begin{array}{l}\text { endix A of Ind AS } 11 \text { deals with accounting } \\
\text { ects involved in such arrangements \& } \\
\text { pendix B deals with disclosures of such } \\
\text { angements. }\end{array}$ & $\begin{array}{l}\text { Does not deal with accounting for } \\
\text { Service Concession Arrangements }\end{array}$ \\
\hline
\end{tabular}

Ind AS 12: Income Taxes-(IMPORTANT)

\begin{tabular}{|c|c|c|c|}
\hline SN & Basis of Differences & Ind AS 12: Income Taxes & $\begin{array}{l}\text { AS 22: Accounting for Taxes } \\
\text { on Income }\end{array}$ \\
\hline 1 & $\begin{array}{l}\text { Approach for creating } \\
\text { Deferred Tax }\end{array}$ & Based on balance sheet approach & $\begin{array}{l}\text { Based on income statement } \\
\text { approach }\end{array}$ \\
\hline 2 & $\begin{array}{l}\text { Recognition of DTA for } \\
\text { unabsorbed depreciation } \\
\text { or carry forward of losses }\end{array}$ & $\begin{array}{l}\text { Same criteria for recognising deferred tax arising } \\
\text { from Unabsorbed depreciation or carry forward of } \\
\text { losses as in case of deductible temporary } \\
\text { differences. }\end{array}$ & $\begin{array}{l}\text { DTA are recognised only if here } \\
\text { should be virtual certainty supported } \\
\text { by convincing evidence }\end{array}$ \\
\hline 3 & $\begin{array}{l}\text { Disclosure of DTA and DTL } \\
\text { in Balance Sheet }\end{array}$ & $\begin{array}{l}\text { Does not deal with this aspect except in } \\
\text { accordance with the requirements of Ind AS } 1 .\end{array}$ & $\begin{array}{l}\text { Deals with disclosure of DTA and } \\
\text { DTL. }\end{array}$ \\
\hline 4 & $\begin{array}{l}\text { DTA/DTL arising out of } \\
\text { Revaluation of Assets. }\end{array}$ & $\begin{array}{l}\text { Shall be measured on the basis of tax } \\
\text { consequences from the sale of asset rather than } \\
\text { through use. }\end{array}$ & Does not deal with this aspect. \\
\hline 5 & $\begin{array}{l}\text { Guidance for Recognition } \\
\text { of Deferred Tax in a Tax } \\
\text { Holiday Period }\end{array}$ & Does not specifically deal with these situations. & $\begin{array}{l}\text { Specially Provides guidance } \\
\text { regarding recognition of DT in Tax } \\
\text { Holiday under Sec } 80-\mathrm{IA}, 80- \\
\mathrm{IB}, 10 \mathrm{~A} \& 10 \mathrm{~B}\end{array}$ \\
\hline 6 & Disclosure Requirements & More detailed. & Less detailed. \\
\hline
\end{tabular}


International Journal of Trend in Scientific Research and Development (IJTSRD) @ www.ijtsrd.com eISSN: 2456-6470

IND AS 16:- Property, Plant and Equipment

\begin{tabular}{|l|l|l|l|}
\hline SN & Basis of Differences & \multicolumn{1}{|c|}{ IND AS 16:- Property, Plant and Equipment } & \multicolumn{1}{c|}{ Amended AS 10:- PPE } \\
\hline 1. & $\begin{array}{l}\text { Fixed Assets retired } \\
\text { from Active Use and } \\
\text { Held for Sale }\end{array}$ & $\begin{array}{l}\text { Ind AS 16 does not deal with the assets 'held for sale' } \\
\text { because the treatment of such assets is covered in Ind } \\
\text { AS 105, Non-current Assets Held for Sale and } \\
\text { Discontinued Operations. }\end{array}$ & $\begin{array}{l}\text { Deals with accounting for } \\
\text { items of fixed assets retired } \\
\text { from active use and held for } \\
\text { sale. }\end{array}$ \\
\hline 2. & $\begin{array}{l}\text { Stripping Costs in the } \\
\text { Production Phase of a } \\
\text { Surface Mine }\end{array}$ & $\begin{array}{l}\text { Provides guidance on measuring 'Stripping Costs in the } \\
\text { Production Phase of a Surface Mine'. }\end{array}$ & $\begin{array}{l}\text { Does not contain this } \\
\text { guidance. }\end{array}$ \\
\hline
\end{tabular}

Ind AS 17: Leases

\begin{tabular}{|c|l|l|l|}
\hline SN & \multicolumn{1}{|c|}{ Basis of Differences } & \multicolumn{1}{|c|}{ Ind AS 17: Leases } & \multicolumn{1}{c|}{ AS 19: Leases } \\
\hline 1 & $\begin{array}{l}\text { Excludes leases of land from its } \\
\text { scope }\end{array}$ & $\begin{array}{l}\text { Does not have exclusion land and has } \\
\text { specific provisions dealing with leases of } \\
\text { land and building. }\end{array}$ & $\begin{array}{l}\text { Excludes leases of land from } \\
\text { its scope }\end{array}$ \\
\hline 2 & Residual Value definition & Deleted & Given \\
\hline 3 & $\begin{array}{l}\text { Inception of Lease and } \\
\text { Commencement of Lease }\end{array}$ & $\begin{array}{l}\text { Makes a distinction between inception of } \\
\text { lease and commencement of lease. }\end{array}$ & No distinction. \\
\hline 4 & $\begin{array}{l}\text { Current/Non-current } \\
\text { Classification }\end{array}$ & $\begin{array}{l}\text { Requires current/non-current classification } \\
\text { of lease Liabilities }\end{array}$ & $\begin{array}{l}\text { No such provision. } \\
\text { lease and Leaseback as finance }\end{array}$ \\
\hline 6 & $\begin{array}{l}\text { Accounting for Incentives } \\
\text { in the Case of Operating Leases }\end{array}$ & No amortisation method is given & $\begin{array}{l}\text { Deferred profit/loss and } \\
\text { amortised in the ratio of } \\
\text { depreciation. }\end{array}$ \\
\hline 7 & Escalation treatment & $\begin{array}{l}\text { In case of lease rental, is in the line with } \\
\text { inflation }\end{array}$ & No guidelines is given \\
\hline
\end{tabular}

Ind AS 18: Revenue

\begin{tabular}{|c|c|c|c|}
\hline SN & $\begin{array}{c}\text { Basis of } \\
\text { Differences }\end{array}$ & Ind AS 18: Revenue & AS 9: Revenue \\
\hline 1 & Definition of Revenue & $\begin{array}{l}\text { Broad definition of 'revenue' is given because it covers } \\
\text { all economic benefits that arise in the ordinary course } \\
\text { of activities of an entity which result in increases in } \\
\text { equity, other than increases relating to contributions } \\
\text { from equity participants. } N: 2456-6470\end{array}$ & $\begin{array}{l}\text { Gross inflow of cash, or } \\
\text { receivables arising in the course } \\
\text { of the ordinary activities of an } \\
\text { enterprise from the sale of goods, } \\
\text { rendering of services, \&interest, } \\
\text { Royalties \&dividends. }\end{array}$ \\
\hline 2 & $\begin{array}{l}\text { Measurement of } \\
\text { Revenue }\end{array}$ & $\begin{array}{l}\text { Revenue to be measured at fair value of the } \\
\text { consideration received or receivable. }\end{array}$ & $\begin{array}{l}\text { Revenue is recognised at the } \\
\text { Nominal amount of consideration } \\
\text { receivable. }\end{array}$ \\
\hline 3 & Barter Transactions & $\begin{array}{l}\text { Deals with the exchange of goods and services } \backslash \text { with } \\
\text { goods and services of similar and dissimilar nature. } \\
\text { Specific guidance is given regarding } \backslash \text { barter } \\
\text { transactions Involving advertising } \backslash \backslash \text { services. }\end{array}$ & $\begin{array}{l}\text { This aspect is not dealt with in } \\
\text { the existing AS } 9\end{array}$ \\
\hline 4. & $\begin{array}{l}\text { Recognition of } \\
\text { Separately } \\
\text { Identifiable } \\
\text { Components } \\
\end{array}$ & $\begin{array}{l}\text { Guidance on application of recognition criteria to the } \\
\text { separately identifiable components of a single } \\
\text { transaction in order to reflect the substance of the } \\
\text { transaction. }\end{array}$ & $\begin{array}{l}\text { Does not specifically deal with } \\
\text { the same. }\end{array}$ \\
\hline 5 & $\begin{array}{l}\text { Recognition of } \\
\text { Interest }\end{array}$ & $\begin{array}{l}\text { Interest to be recognised using effective interest rate } \\
\text { method(EIR) as set out in Ind AS 109, Financial } \\
\text { Instruments }\end{array}$ & $\begin{array}{l}\text { Requires the recognition of } \\
\text { revenue from interest on time } \\
\text { Proportion basis. }\end{array}$ \\
\hline 6 & $\begin{array}{l}\text { Guidance Regarding } \\
\text { Revenue Recognition } \\
\text { in Specific Cases }\end{array}$ & $\begin{array}{l}\text { Provides guidance regarding revenue recognition in } \\
\text { case the entity is under any obligation to provide free } \\
\text { or discounted goods or services or award credits to its } \\
\text { Customers due to any customer loyalty programme. }\end{array}$ & Does not deal with this aspect. \\
\hline 7 & $\begin{array}{l}\text { Disclosure of Excise } \\
\text { Duty }\end{array}$ & Does not specifically deal with the same. & $\begin{array}{l}\text { Specifically deals with disclosure } \\
\text { of excise duty as a deduction } \\
\text { from revenue from sales } \\
\text { transactions. }\end{array}$ \\
\hline 8. & $\begin{array}{l}\text { Disclosure } \\
\text { Requirements }\end{array}$ & Disclosure requirements are given more. & Less disclosure requirements. \\
\hline
\end{tabular}


International Journal of Trend in Scientific Research and Development (IJTSRD) @ www.ijtsrd.com eISSN: 2456-6470

Ind AS 19: Employee Benefits

\begin{tabular}{|c|c|c|c|}
\hline SN & Basis of Differences & Ind AS 19: Employee Benefits & AS 15: Employee Benefits \\
\hline 1 & Constructive Obligations & $\begin{array}{l}\text { Employee benefits arising from constructive } \\
\text { obligations are also covered }\end{array}$ & Not deal. \\
\hline 2 & Definition of Employee & Includes directors & Includes whole-time directors \\
\hline 3 & $\begin{array}{l}\text { Contractual Agreement } \\
\text { between a Multi- employer } \\
\text { Plan and its Participants }\end{array}$ & $\begin{array}{l}\text { Deals with situations where surplus in the } \\
\text { plan will be distributed to the participants }\end{array}$ & Does not deal \\
\hline 4 & Qualified Actuary & $\begin{array}{l}\text { Encourages, but does not require, involving } \\
\text { a qualified Actuary in the measurement of } \\
\text { DBO. }\end{array}$ & $\begin{array}{l}\text { Does not specifically encourage } \\
\text { the same }\end{array}$ \\
\hline 5 & Actuarial Gains and Losses & $\begin{array}{l}\text { Shall be recognised in other comprehensive } \\
\text { income }\end{array}$ & Recognised in the profit \& loss \\
\hline 6 & Financial Assumptions & Shall be based on market expectations. & Does not clarify the same. \\
\hline 7 & $\begin{array}{l}\text { Timing of Recognition of } \\
\text { Termination Benefits }\end{array}$ & More guidance has been given. & ------ \\
\hline
\end{tabular}

Ind AS 20: Accounting for Government Grants and Disclosure of Government Assistance

\begin{tabular}{|c|c|c|c|c|c|}
\hline SN & \multicolumn{2}{|l|}{ Basis of Differences } & $\begin{array}{c}\text { Ind AS 20: Accounting for } \\
\text { Government Grants and Disclosur } \\
\text { of Government Assistance }\end{array}$ & & $\begin{array}{l}\text { AS 12: Accounting for } \\
\text { Government Grants }\end{array}$ \\
\hline 1 & \multicolumn{2}{|l|}{$\begin{array}{l}\text { Grant in respect of Non } \\
\text { Depreciable Assets }\end{array}$} & $\begin{array}{l}\text { Grants should be recognised as income ove } \\
\text { the periods which bear the cost of meeting } \\
\text { the obligation. }\end{array}$ & & $\begin{array}{l}\text { Shown as capital reserve which is } \\
\text { a part of shareholders' funds }\end{array}$ \\
\hline 2 & \multicolumn{2}{|l|}{$\begin{array}{l}\text { Government Grants in the } \\
\text { Nature of Promoters } \\
\text { Contribution }\end{array}$} & $\begin{array}{l}\text { Grants should be recognised as income ove } \\
\text { the periods which bear the cost of meeting } \\
\text { the obligation. }\end{array}$ & & $\begin{array}{l}\text { Shown as capital reserve which is } \\
\text { a part of shareholders' funds }\end{array}$ \\
\hline 3 & \multicolumn{2}{|c|}{$\begin{array}{l}\text { Grant in kind given Free or at a } \\
\text { Concessional Rate }\end{array}$} & Recorded at a Fair value & & Recorded at a nominal value \\
\hline 4 & \multicolumn{2}{|l|}{ Government Assistance } & Deals with Government Assistance & & Not deals \\
\hline 5 & \multicolumn{2}{|l|}{ Return of grant. } & $\begin{array}{l}\text { Considered as change in Accounting } \\
\text { Estimates. Trond in Sciontific }\end{array}$ & & Treated as extraordinary items \\
\hline 6 & \multicolumn{2}{|l|}{ Loans at Concessional Rate } & $\begin{array}{l}\text { A below-market rate of interest should be } \\
\text { recognised as grant. }\end{array}$ & & No provision given. \\
\hline \multicolumn{6}{|c|}{ Ind AS 21: The Effects of Changes in Foreign Exchange Rates } \\
\hline$\overline{\text { SN }}$ & Basis of Differences & $\mathrm{Ir}$ & $\begin{array}{l}\text { d AS 21: The Effects of Changes in } \\
\text { Foreign Exchange Rates }\end{array}$ & & $\begin{array}{l}\text { 11: The Effects of Changes in } \\
\text { Foreign Exchange Rates }\end{array}$ \\
\hline 1 & $\begin{array}{l}\text { Forward Exchange } \\
\text { Contracts \& other } \\
\text { similar Financial } \\
\text { Instruments }\end{array}$ & $\begin{array}{l}\text { Excl } \\
\text { cont } \\
\text { inst } \\
\text { with }\end{array}$ & $\begin{array}{l}\text { udes from its scope forward exchange } \\
\text { racts and other similar financial } \\
\text { uments, which are treated in accordance } \\
\text { Ind AS } 109 .\end{array}$ & $\begin{array}{l}\text { Doe } \\
\text { such }\end{array}$ & $\begin{array}{l}\text { s not such exclude accounting for } \\
\text { h contracts. }\end{array}$ \\
\hline 2 & $\begin{array}{l}\text { Exchange Differences } \\
\text { arising on Translation of } \\
\text { Certain Long- } \\
\text { term Monetary Items } \\
\text { from Foreign Currency } \\
\text { to Functional Currency. }\end{array}$ & $\begin{array}{l}\text { Doe } \\
\text { mon } \\
\text { stat } \\
\text { Ind } \\
\text { prev } \\
\text { prov } \\
\text { cont } \\
\text { opte } \\
\text { mon }\end{array}$ & $\begin{array}{l}\text { not apply to long-term foreign currency } \\
\text { etary items recognised in the financial } \\
\text { ments before the beginning of the first } \\
\text { IS financial reporting period as per the } \\
\text { ious GAAP, i.e. AS } 11 \text {. However, as } \\
\text { ided in Ind AS } 101 \text {, such an entity may } \\
\text { inue to apply the accounting policy so } \\
\text { d for such long-term foreign currency } \\
\text { etary items as per the previous GAAP. }\end{array}$ & $\begin{array}{l}\text { Give } \\
\text { exch } \\
\text { equ } \\
\text { loss } \\
\text { liabi } \\
\text { rela } \\
\text { The } \\
\text { reco } \\
\text { the }\end{array}$ & $\begin{array}{l}\text { es an option to recognise such } \\
\text { hange differences directly in } \\
\text { ity, to be transferred to profit or } \\
\text { over the life of the relevant } \\
\text { ility/asset if such items are not } \\
\text { ted to acquisition of fixed assets. } \\
\text { FED related to fixed assets can be } \\
\text { ognised as part of the cost of } \\
\text { asset. }\end{array}$ \\
\hline 3 & $\begin{array}{l}\text { Approach for } \\
\text { Translation }\end{array}$ & Base & d on the functional currency approach. & $\begin{array}{l}\text { Bas } \\
\text { acco } \\
\text { ope }\end{array}$ & $\begin{array}{l}\text { ed on IFO \& NIFO approach for } \\
\text { ounting for a foreign } \\
\text { ration. }\end{array}$ \\
\hline 4 & Presentation Currency & $\begin{array}{l}\text { Pres } \\
\text { loca } \\
\text { in th }\end{array}$ & $\begin{array}{l}\text { entation currency can be different from } \\
\text { currency and it gives detailed guidance } \\
\text { is regard }\end{array}$ & Doe & s not explicitly state so. \\
\hline
\end{tabular}


International Journal of Trend in Scientific Research and Development (IJTSRD) @ www.ijtsrd.com eISSN: 2456-6470

Ind AS 23: Borrowing Costs

\begin{tabular}{|c|l|l|l|}
\hline SN & Basis of Differences & \multicolumn{1}{|c|}{ Ind AS 23: Borrowing Costs } & AS 16: Borrowing Costs \\
\hline 1 & $\begin{array}{l}\text { Scope (Relaxation in } \\
\text { Capitalization) }\end{array}$ & $\begin{array}{l}\text { Borrowing cost need not be capitalised } \\
\text { Inventories that are manufactured or otherwise } \\
\text { produced, in large quantities on a repetitive basis. }\end{array}$ & $\begin{array}{l}\text { Does not provide for such } \\
\text { relaxation scope }\end{array}$ \\
\hline 2 & $\begin{array}{l}\text { Reporting in } \\
\text { Hyperinflationary } \\
\text { Economies }\end{array}$ & $\begin{array}{l}\text { Part of the borrowing costs that compensates for } \\
\text { inflation should be expensed, not capitalized in } \\
\text { respect of qualifying assets. }\end{array}$ & No Such Standard in India. \\
\hline 3 & Capitalization Rate & Requires Disclosure of Capitalisation Rate & Does not require \\
\hline 4 & Effective interest Method & $\begin{array}{l}\text { Interest expenses to be computed by using of effective } \\
\text { interest Method. }\end{array}$ & No Such Requirement. \\
\hline
\end{tabular}

Ind AS 24: Related Party Disclosures

\begin{tabular}{|c|c|c|c|c|c|}
\hline SN & Basis of Differences & \multicolumn{2}{|c|}{ Ind AS 24: Related Party Disclosures } & \multicolumn{2}{|c|}{ AS 18: Related Party Disclosures } \\
\hline 1. & Definition of Relative & \multicolumn{2}{|c|}{$\begin{array}{l}\text { Uses the term - a close member of the } \\
\text { family of a person. }\end{array}$} & \multicolumn{2}{|c|}{$\begin{array}{l}\text { Uses the term - relatives of an } \\
\text { individual. }\end{array}$} \\
\hline 2 & Relative covers & \multicolumn{2}{|c|}{$\begin{array}{l}\text { Children, spouse or domestic partner, } \\
\text { brother, sister, father and mother; children } \\
\text { of that person's spouse or domestic } \\
\text { partner; and dependants of that person or } \\
\text { that person's spouse or domestic partner. }\end{array}$} & \multicolumn{2}{|c|}{$\begin{array}{l}\text { Covers the spouse, son, daughter, } \\
\text { brother, sister, father and mother }\end{array}$} \\
\hline 3 & KMP & \multicolumn{2}{|c|}{ Covers KMP of the parent as well } & \multicolumn{2}{|c|}{ KMP of the entity only } \\
\hline 4 & $\begin{array}{l}\text { Related Parties in case of } \\
\text { Joint Venture }\end{array}$ & \multicolumn{2}{|c|}{$\begin{array}{l}\text { Co-venturers or co-associates are related to } \\
\text { each other. }\end{array}$} & \multicolumn{2}{|c|}{$\begin{array}{l}\text { Co-venturers or co-associates are not } \\
\text { related to each other }\end{array}$} \\
\hline 5 & Post-employment Benefits & \multicolumn{2}{|c|}{$\begin{array}{l}\text { Specifically includes post-employment } \\
\text { benefit plans for } \\
\text { the benefit of employees of an entity or its } \\
\text { related entity as related parties. }\end{array}$} & \multicolumn{2}{|c|}{$\begin{array}{l}\text { Does not specifically cover entities } \\
\text { that are post-employment } \\
\text { benefit plans, as related parties }\end{array}$} \\
\hline 6 & Next Most Senior Parent & \multicolumn{2}{|c|}{$\begin{array}{l}\text { Additional disclosure is required for such } \\
\text { parent. }\end{array}$} & \multicolumn{2}{|c|}{ No such provision. } \\
\hline 7 & $\begin{array}{l}\text { Disclosure for } \\
\text { Compensation }\end{array}$ & \multicolumn{2}{|c|}{$\begin{array}{l}\text { Extended disclosures for compensation of } \\
\text { KMP under different categories. }\end{array}$} & \multicolumn{2}{|c|}{ Not required. } \\
\hline 8 & $\begin{array}{l}\text { Disclosure of 'Amount of } \\
\text { the Transactions' vs } \\
\text { 'Volume of the } \\
\text { Transactions }\end{array}$ & \multicolumn{2}{|c|}{$\begin{array}{l}\text { The amount of the transactions need to be } \\
\text { disclosed }\end{array}$} & \multicolumn{2}{|c|}{$\begin{array}{l}\text { Option to disclose the - Volume of the } \\
\text { transactions either as an amount or as } \\
\text { an appropriate } \\
\text { proportion }\end{array}$} \\
\hline 9 & $\begin{array}{l}\text { Government Related } \\
\text { Entities }\end{array}$ & \multicolumn{2}{|c|}{$\begin{array}{l}\text { Disclosures of certain information by the } \\
\text { government related entities. }\end{array}$} & \multicolumn{2}{|c|}{$\begin{array}{l}\text { Presently exempts the disclosure of } \\
\text { such information }\end{array}$} \\
\hline \multicolumn{6}{|c|}{ Earnings Per share } \\
\hline 1 & \multicolumn{2}{|l|}{$\begin{array}{l}\text { Disclosure of EPS with \& } \\
\text { Without Extraordinary Items }\end{array}$} & \multicolumn{3}{|c|}{ No Requirement } \\
\hline 2 & \multicolumn{2}{|l|}{$\begin{array}{l}\text { Basic and Diluted EPS from } \\
\text { Continuing and Discontinued } \\
\text { Operations }\end{array}$} & \multicolumn{2}{|c|}{$\begin{array}{l}\text { Requires presentation of basic and diluted } \\
\text { EPS from continuing and discontinued } \\
\text { operations separately }\end{array}$} & $\begin{array}{l}\text { Not require any such } \\
\text { disclosure }\end{array}$ \\
\hline 3 & \multicolumn{2}{|c|}{$\begin{array}{l}\text { Options held by the Entity on its } \\
\text { Shares }\end{array}$} & \multicolumn{2}{|c|}{$\begin{array}{l}\text { Specifically deal with options held by the } \\
\text { entity on its shares }\end{array}$} & Not deals. \\
\hline
\end{tabular}

Ind AS 34: Interim Financial Reporting

\begin{tabular}{|c|c|c|c|}
\hline SN & Basis of Differences & $\begin{array}{c}\text { Ind AS 34: Interim Financial } \\
\text { Reporting }\end{array}$ & $\begin{array}{l}\text { AS 25: Interim Financial } \\
\text { Reporting }\end{array}$ \\
\hline 1. & $\begin{array}{l}\text { Condensed statement of change } \\
\text { in equity }\end{array}$ & $\begin{array}{l}\text { Required with condensed BS, PL and } \\
\text { Cash Flow. }\end{array}$ & $\begin{array}{l}\text { Not Required with condensed BS, PL } \\
\text { and Cash flow. }\end{array}$ \\
\hline 2 & Reversal of Impairment Loss & $\begin{array}{l}\text { Prohibits reversal of impairment loss } \\
\text { recognised in a previous interim period } \\
\text { in respect of goodwill or an investment. }\end{array}$ & No such Provision \\
\hline 3 & $\begin{array}{l}\text { Parent's Separate Statements \& } \\
\text { the Consolidated Financial } \\
\text { Statements in the Entity's } \\
\text { Interim Report }\end{array}$ & $\begin{array}{l}\text { Neither requires nor prohibits the } \\
\text { inclusion of the parent's separate } \\
\text { statements in the entity's interim } \\
\text { report prepared on a consolidated } \\
\text { basis. }\end{array}$ & $\begin{array}{l}\text { It included the consolidated financial } \\
\text { statements in addition to the } \\
\text { separate financial statements in the } \\
\text { interim financial report. }\end{array}$ \\
\hline
\end{tabular}


International Journal of Trend in Scientific Research and Development (IJTSRD) @ www.ijtsrd.com eISSN: 2456-6470

\begin{tabular}{|c|l|l|l|}
\hline 4 & Accounting Policies & $\begin{array}{l}\text { Ind AS 34 requires requirements of AS } \\
\text { 25 plus additionally requires the } \\
\text { information in respect of methods of } \\
\text { computation followed. }\end{array}$ & $\begin{array}{l}\text { Notes of interim financial statements } \\
\text { require, containing a statement that } \\
\text { the same accounting policies are } \\
\text { followed in the interim financial } \\
\text { statements. }\end{array}$ \\
\hline 5 & $\begin{array}{l}\text { Contingent Liabilities and } \\
\text { Contingent Assets }\end{array}$ & $\begin{array}{l}\text { Requires information on both } \\
\text { contingent liabilities and contingent } \\
\text { assets, if they are significant. }\end{array}$ & $\begin{array}{l}\text { Requires information on contingent } \\
\text { liabilities only }\end{array}$ \\
\hline 6 & Extraordinary Items & Not Required & Required \\
\hline 7 & Change in Accounting Policy & $\begin{array}{l}\text { Restatement of prior interim financial } \\
\text { statement and annual financial } \\
\text { statement. }\end{array}$ & $\begin{array}{l}\text { Restating of prior interim periods } \\
\text { financial statement. }\end{array}$ \\
\hline
\end{tabular}

Ind AS 36: Impairment of Assets

\begin{tabular}{|c|c|c|c|}
\hline SN & Basis of Differences & Ind AS 36: Impairment of Assets & AS 28: Impairment of Assets \\
\hline 1 & $\begin{array}{l}\text { Applies to Financial } \\
\text { Assets }\end{array}$ & $\begin{array}{l}\text { Applies to financial assets classified as } \\
\text { subsidiaries, joint ventures and associates. }\end{array}$ & Not Applicable \\
\hline 2 & Exclude biological assets & $\begin{array}{l}\text { Specifically excludes biological assets related } \\
\text { to agricultural activity }\end{array}$ & $\begin{array}{l}\text { Not specifically exclude biological } \\
\text { assets }\end{array}$ \\
\hline 3 & $\begin{array}{l}\text { Mandatory Annual } \\
\text { Impairment Testing. }\end{array}$ & $\begin{array}{l}>\text { An intangible asset with an indefinite useful } \\
\text { life } \\
>\text { Intangible asset not yet available for use } \\
>\text { Goodwill acquired in a business combination. }\end{array}$ & $\begin{array}{l}\text { No annual impairment testing } \\
\text { unless there is an indication of } \\
\text { impairment. }\end{array}$ \\
\hline 4 & Reversal of Goodwill & $\begin{array}{l}\text { Prohibits the recognition of reversals of } \\
\text { impairment loss for goodwill. }\end{array}$ & $\begin{array}{l}\text { Reversed in a subsequent period } \\
\text { when it was caused by a specific } \\
\text { external event }\end{array}$ \\
\hline 5 & $\begin{array}{l}\text { Bottom up and Top Down } \\
\text { Test }\end{array}$ & $\begin{array}{l}\text { No Bottom up and Top Down Test for } \\
\text { allocation of Goodwill. }\end{array}$ & $\begin{array}{l}\text { Bottom up and Top Down Test for } \\
\text { allocation of Goodwill. }\end{array}$ \\
\hline 6 & $\begin{array}{l}\text { Guidance for the value in } \\
\text { use of an asset, using PV } \\
\text { techniques }\end{array}$ & Additional guidlines given. Scientific & Brief guidelines given. \\
\hline 7 & Disclosures & More Disclosure & Less Disclosure \\
\hline \multicolumn{4}{|c|}{ Ind AS 37: Provisions, Contingent Liabilities and Contingent Assets } \\
\hline SN & Basis of Differences & $\begin{array}{l}\text { Ind AS 37: Provisions, Contingent } \\
\text { Liabilities and Contingent Assets }\end{array}$ & $\begin{array}{l}\text { AS 29: Provisions, Contingent } \\
\text { Liabilities \& Contingent Assets. }\end{array}$ \\
\hline 1 & $\begin{array}{l}\text { Constructive obligations } \\
\text { and Change in the } \\
\text { Definition of Provision } \\
\text { and Obligating Event }\end{array}$ & $\begin{array}{l}>\quad \text { "Legal obligation" and "constructive } \\
\text { obligation" have been inserted and defined } \\
\text { in Ind AS } 37 . \\
>\quad \text { Provision can be created from } \\
\text { Constructive obligation. }\end{array}$ & $\begin{array}{l}\text { Provision can be created only in } \\
\text { case of Business practice. }\end{array}$ \\
\hline 2 & Discounting Provisions & $\begin{array}{l}\text { Discounting provisions, if effect of the time } \\
\text { value of money is material. }\end{array}$ & $\begin{array}{l}\text { Prohibits discounting the amounts } \\
\text { of provisions except in case of } \\
\text { decommissioning, restoration and } \\
\text { similar liabilities that are recognised } \\
\text { as cost of PPE under AS-10. }\end{array}$ \\
\hline 3 & $\begin{array}{l}\text { Disclosure of Contingent } \\
\text { Assets }\end{array}$ & $\begin{array}{l}\text { Disclosure of contingent assets in the financial } \\
\text { statements }\end{array}$ & $\begin{array}{l}\text { Disclosure in the report of the } \\
\text { approving authority. }\end{array}$ \\
\hline 4 & Impairment loss & $\begin{array}{l}\text { An entity should recognise any impairment } \\
\text { loss that has occurred on assets dedicated to } \\
\text { Onerous contract. }\end{array}$ & No Such Provision. \\
\hline
\end{tabular}

Ind AS 38: Intangible Assets

\begin{tabular}{|c|l|l|l|}
\hline SN & Basis of Differences & \multicolumn{1}{|c|}{ IND AS 38: Intangible Assets } & \multicolumn{1}{c|}{ AS 26: Intangible Assets } \\
\hline 1 & Exclusions & $\begin{array}{l}\text { Ind AS 38 does not include any exclusion in } \\
\text { relation to accounting for discount or premium } \\
\text { relating to borrowings and ancillary costs } \\
\text { incurred in. }\end{array}$ & $\begin{array}{l}\text { Does not apply to accounting for } \\
\text { discount or premium relating to } \\
\text { borrowings and ancillary costs } \\
\text { incurred in. }\end{array}$ \\
\hline 2 & $\begin{array}{l}\text { Removed from Definition } \\
\text { of Intangible Assets }\end{array}$ & $\begin{array}{l}\text { The requirement for the asset to be held for } \\
\text { use in the production or supply of goods or } \\
\text { services, for rental to others, or for } \\
\text { administrative purposes has been removed } \\
\text { from the definition. }\end{array}$ & Included \\
\hline
\end{tabular}


International Journal of Trend in Scientific Research and Development (IJTSRD) @ www.ijtsrd.com eISSN: 2456-6470

\begin{tabular}{|c|c|c|c|}
\hline 3 & $\begin{array}{l}\text { Payment Deferred } \\
\text { beyond Normal Credit } \\
\text { Terms }\end{array}$ & $\begin{array}{l}\text { Difference between cash amount and the total } \\
\text { payments is recognised as interest expense } \\
\text { over the period of credit unless it is capitalised } \\
\text { in Ind AS } 23\end{array}$ & No such provision \\
\hline 4 & $\begin{array}{l}\text { Acquired in Business } \\
\text { Combination }\end{array}$ & $\begin{array}{l}\text { Deals in detail in respect of intangible assets } \\
\text { acquired in a business combination }\end{array}$ & $\begin{array}{l}\text { Acquired in an amalgamation in the } \\
\text { nature of purchase is dealt. }\end{array}$ \\
\hline 5 & $\begin{array}{l}\text { Subsequent Expenditure } \\
\text { on R\&D Project Process }\end{array}$ & $\begin{array}{l}\text { Gives guidance for the treatment of such } \\
\text { expenditure }\end{array}$ & No guidance \\
\hline 6 & $\begin{array}{l}\text { Intangible Assets } \\
\text { Acquired in Exchange }\end{array}$ & $\begin{array}{l}\text { Should be recognised at the fair value of the } \\
\text { asset given up. }\end{array}$ & $\begin{array}{l}\text { Fair market value of the asset } \\
\text { acquired or surrendered which has } \\
\text { more clearly evident. }\end{array}$ \\
\hline 7 & Useful Life. & The useful life can even be indefinite. & Cannot exceed 10 years \\
\hline 8 & $\begin{array}{l}\text { Valuation Model as } \\
\text { Accounting Policy }\end{array}$ & $\begin{array}{l}\text { Permits an entity to choose either the cost } \\
\text { model or the revaluation model }\end{array}$ & Revaluation model is not permitted \\
\hline 9 & Legal Life & Useful life shorter than the legal life & No such Provision \\
\hline 10 & $\begin{array}{l}\text { Change in Method of } \\
\text { Amortization }\end{array}$ & Change in accounting estimate. & Change in accounting policy \\
\hline 11 & $\begin{array}{l}\text { Annual Impairment } \\
\text { Testing }\end{array}$ & $\begin{array}{l}\text { Annual impairment testing of an intangible } \\
\text { asset not yet available for use }\end{array}$ & No such requirement \\
\hline 12 & Disclosures & More Disclosure & Less Disclosure \\
\hline
\end{tabular}

Ind AS 103: Business Combinations

\begin{tabular}{|l|l|l|l|}
\hline SN & Basis of Differences & \multicolumn{1}{|c|}{ Ind AS 103: Business Combinations } & \multicolumn{1}{|c|}{ AS 14: Amalgamations } \\
\hline 1 & Scope & A Business combination has a wider scope. & Deals only with amalgamation. \\
\hline 3 & Methods for Accounting & $\begin{array}{l}\text { Prescribes only the acquisition method for } \\
\text { every business combination. }\end{array}$ & $\begin{array}{l}\text { Two methods (a) the pooling of } \\
\text { interest method and (b) the } \\
\text { purchase method }\end{array}$ \\
\hline 4 & Amortisation of Goodwill & $\begin{array}{l}\text { At fair value under acquisition method } \\
\text { impairment on annual basis in accordance } \\
\text { with Ind AS 36 }\end{array}$ & $\begin{array}{l}\text { At their existing book values or at } \\
\text { fair values under the purchase } \\
\text { method }\end{array}$ \\
\hline 5 & $\begin{array}{l}\text { Contingent Consideration } \\
\text { in case of business } \\
\text { combination }\end{array}$ & $\begin{array}{l}\text { Deals with an obligation of the acquirer to } \\
\text { transfer additional assets or equity interests } \\
\text { to the former owners of an acquire if specified } \\
\text { future events occur or conditions are met. }\end{array}$ & $\begin{array}{l}\text { Does not provide specific guidance } \\
\text { on this aspect. }\end{array}$ \\
\hline 6 & Bargain Purchase Gain & $\begin{array}{l}\text { Bargain purchase gain arising on business } \\
\text { combination to be recognised in other } \\
\text { comprehensive income and accumulated in } \\
\text { equity as capital reserve. }\end{array}$ & $\begin{array}{l}\text { The excess amount is treated as } \\
\text { capital reserve }\end{array}$ \\
\hline
\end{tabular}

Ind AS 105: Non-current Assets Held for Sale and Discontinued Operations

\begin{tabular}{|c|l|l|l|}
\hline SN & \multicolumn{1}{|c|}{ Basis of Differences } & $\begin{array}{l}\text { Ind AS 105: Non-current Assets Held } \\
\text { for Sale and Discontinued Operations. }\end{array}$ & \multicolumn{1}{|c|}{$\begin{array}{c}\text { AS 24: Discontinuing } \\
\text { Operations }\end{array}$} \\
\hline 1. & Scope and Objective & $\begin{array}{l}\text { The accounting for non-current assets held } \\
\text { for sale, and the presentation and disclosure } \\
\text { of discontinued operations }\end{array}$ & $\begin{array}{l}\text { Principles for reporting information } \\
\text { about discontinuing operations }\end{array}$ \\
\hline 2 & Cash Flow Statement & Does not mention so. & $\begin{array}{l}\text { Requirements related to CFS are } \\
\text { applicable when the enterprise } \\
\text { presents a CFS }\end{array}$ \\
\hline 4 & $\begin{array}{l}\text { Discontinued v/s } \\
\text { Discontinuing Operations }\end{array}$ & $\begin{array}{l}\text { A discontinued operation is a component of } \\
\text { an entity that either has been disposed of or } \\
\text { is classified as held for sale }\end{array}$ & $\begin{array}{l}\text { There is no concept of discontinued } \\
\text { operations but it deals with } \\
\text { discontinuing operations. }\end{array}$ \\
\hline 5 & Time Period & $\begin{array}{l}\text { Within one year from the date of } \\
\text { classification with certain exceptions }\end{array}$ & $\begin{array}{l}\text { Does not specify any time period } \\
\text { in this regard as it relates to } \\
\text { discontinuing operations }\end{array}$ \\
\hline 6 & Measurement & $\begin{array}{l}\text { Does not mention so as it relates to } \\
\text { discontinued operation. }\end{array}$ & $\begin{array}{l}\text { AS 24 specifies about the initial } \\
\text { disclosure event in respect to a } \\
\text { discontinuing operation }\end{array}$ \\
\hline 7 & $\begin{array}{l}\text { Abandonment of Assets is } \\
\text { a discontinuing operation }\end{array}$ & Not classified as a discontinuing operation. & $\begin{array}{l}\text { Classified as a discontinuing } \\
\text { operation }\end{array}$ \\
\hline
\end{tabular}


International Journal of Trend in Scientific Research and Development (IJTSRD) @ www.ijtsrd.com eISSN: 2456-6470

\begin{tabular}{|c|l|l|l|}
\hline 8 & $\begin{array}{l}\text { Guidance Regarding } \\
\text { Measurement of Changes } \\
\text { to a Plan of Change }\end{array}$ & Provides guidance. & $\begin{array}{l}\text { Does not give any specific guidance } \\
\text { regarding this aspect }\end{array}$ \\
\hline
\end{tabular}

Ind AS 108: Operating Segments

\begin{tabular}{|c|l|l|l|}
\hline SN & \multicolumn{1}{|c|}{ Basis of Differences } & \multicolumn{1}{|c|}{ Ind AS 108: Operating Segments } & \multicolumn{1}{c|}{ AS 17: Segment Reporting } \\
\hline 1 & Identification of Segments & $\begin{array}{l}\text { Based on 'management approach', whose } \\
\text { operating results are regularly reviewed } \\
\text { by the entity's chief operating decision } \\
\text { maker. }\end{array}$ & $\begin{array}{l}\text { Two sets of segments; Business and } \\
\text { Geographical segment based on the } \\
\text { risks and returns } \\
\text { approach. }\end{array}$ \\
\hline 2 & $\begin{array}{l}\text { Measurement of Amounts to } \\
\text { be Reported in Segments }\end{array}$ & $\begin{array}{l}\text { On the same basis as that used by the chief } \\
\text { operating decision maker for the purposes } \\
\text { of allocating resources to the segments } \\
\text { and assessing its performance }\end{array}$ & $\begin{array}{l}\text { Segment information to be } \\
\text { prepared in conformity with the } \\
\text { accounting policies adopted for } \\
\text { preparing \& presenting the FS. }\end{array}$ \\
\hline 3 & Aggregation criteria. & $\begin{array}{l}\text { Two or more segments can be aggregated } \\
\text { if they have similar economic } \\
\text { characteristics }\end{array}$ & $\begin{array}{l}\text { No specific guidelines } \\
\text { of entities having single reportable } \\
\text { segment }\end{array}$ \\
\hline & Single Reportable Segment & $\begin{array}{l}\text { Not required to be disclosed. } \\
\text { (Disclosed by way of footnote) }\end{array}$ \\
\hline
\end{tabular}

Ind AS 28: 'Investments in Associates and Joint Ventures'

\begin{tabular}{|c|c|c|c|}
\hline SN & Basis of Differences & $\begin{array}{l}\text { Ind AS } 28 \text { 'Investments in Associates } \\
\text { and Joint Ventures' }\end{array}$ & $\begin{array}{c}\text { AS } 23 \text { 'Accounting for } \\
\text { Investments in Associates in } \\
\text { CFS' }\end{array}$ \\
\hline 1 & Significant Influence & $\begin{array}{l}\text { Power to participate in policy decisions but } \\
\text { not control or joint control over those } \\
\text { policies. }\end{array}$ & $\begin{array}{l}\text { Power to participate in policy } \\
\text { decisions but not control over } \\
\text { those policies. }\end{array}$ \\
\hline 2 & Potential Voting Rights & $\begin{array}{l}\text { Are considered for determining significant } \\
\text { influence (SI). Trend in Scientific }\end{array}$ & $\begin{array}{l}\text { Are nnot considered for } \\
\text { determining SI }\end{array}$ \\
\hline 3 & $\begin{array}{l}\text { Accounting of investment } \\
\text { in associates in the C\&SFS }\end{array}$ & $\begin{array}{l}\text { Equity method should be applied, even if } \\
\text { there is no subsidiary. }\end{array}$ & $\begin{array}{l}\text { Equity method, only if there is a } \\
\text { subsidiary. }\end{array}$ \\
\hline 4 & $\begin{array}{l}\text { Exception to equity } \\
\text { method }\end{array}$ & No exception to equity method 70 & $\begin{array}{l}\text { Exceptions to equity method } \\
\text { are available }\end{array}$ \\
\hline 5 & $\begin{array}{l}\text { Option where a part of the } \\
\text { investment in associate is } \\
\text { held indirectly through } \\
\text { certain specific modes. }\end{array}$ & $\begin{array}{l}\text { The part so held could be measured at fair } \\
\text { value. Equity method to be applied to the } \\
\text { remaining portion. }\end{array}$ & No Such exemption \\
\hline 6 & Share of losses in entity & $\begin{array}{l}\text { Carrying amount of investment with long } \\
\text { term interests shall be considered. } \\
\text { Discontinue when such carrying amount } \\
\text { becomes Nil. }\end{array}$ & $\begin{array}{l}\text { Only carrying amount of } \\
\text { interest shall be considered. }\end{array}$ \\
\hline 7 & Loss of SI over an associate & $\begin{array}{l}\text { Should be recognized in OCI, and reclassified } \\
\text { to SPL on disposal. }\end{array}$ & No specific guidance \\
\hline 8 & $\begin{array}{l}\text { Capital reserve/ negative } \\
\text { goodwill }\end{array}$ & $\begin{array}{l}\text { Should be recognized directly in equity, on } \\
\text { any acquisition }\end{array}$ & $\begin{array}{l}\text { Should be included in carrying } \\
\text { amount of associatebut disclosed } \\
\text { separately. }\end{array}$ \\
\hline 9 & $\begin{array}{l}\text { Uniform accounting } \\
\text { policies }\end{array}$ & $\begin{array}{l}\text { To be followed unless it is impracticable to do } \\
\text { so. }\end{array}$ & $\begin{array}{l}\text { If not practicable, facts to be } \\
\text { disclosed. }\end{array}$ \\
\hline 10 & Reporting date & $\begin{array}{l}\text { The difference in reporting dates should not } \\
\text { be more than } 3 \text { months }\end{array}$ & No specific guidance \\
\hline 11 & Impairment & Objective evidence. & $\begin{array}{l}\text { Recognize any decline other } \\
\text { than temporary. }\end{array}$ \\
\hline
\end{tabular}


International Journal of Trend in Scientific Research and Development (IJTSRD) @ www.ijtsrd.com eISSN: 2456-6470

Ind AS 111- Joint Arrangements

\begin{tabular}{|c|c|c|c|}
\hline SN & Basis of Differences & Ind AS 111-Joint Arrangements & $\begin{array}{l}\text { AS 27- Financial Reporting of } \\
\text { Interests in JV }\end{array}$ \\
\hline 1 & Defined Terms & Joint control, Joint arrangement & Joint control, Joint venture \\
\hline 2 & Accounting Method & $\begin{array}{l}\text { Can either be JO or JV, the classification } \\
\text { depends on rights and obligations of parties } \\
\text { to arrangement. }\end{array}$ & $\begin{array}{l}\text { Prescribes } 3 \text { forms of joint venture: } \\
\text { JCO, JCA, JCE. }\end{array}$ \\
\hline 3 & $\begin{array}{l}\text { Accounting of interest in } \\
\text { jointly controlled entity in } \\
\text { the separate financial } \\
\text { statements }\end{array}$ & $\begin{array}{l}\text { Accounted for either at cost or as per Ind AS } \\
\text { 109. If classified as held for sale, should be } \\
\text { accounted for as per Ind AS 105. Equity } \\
\text { method should be applied if venture does } \\
\text { not prepare separate financial statements }\end{array}$ & $\begin{array}{l}\text { As per AS } 13 \text { at cost less provision } \\
\text { for other than temporary decline }\end{array}$ \\
\hline 4 & $\begin{array}{l}\text { Explanation on the term } \\
\text { near future }\end{array}$ & $\begin{array}{l}\text { It is deleted because it is covered under Ind } \\
\text { AS } 105 .\end{array}$ & Explanation given in Ind AS27 \\
\hline 5 & $\begin{array}{l}\text { Disclosure of ventures share } \\
\text { in post- acquisition reserves } \\
\text { of a jointly } \\
\text { controlled entity }\end{array}$ & No specific guidance & $\begin{array}{l}\text { Shown separately under the } \\
\text { relevant reserve while applying } \\
\text { proportionate consolidation } \\
\text { method. }\end{array}$ \\
\hline 6 & $\begin{array}{l}\text { Accounting in case of JC over } \\
\text { an entity which is a } \\
\text { subsidiary of the entity. }\end{array}$ & No recognition of such cases & Consolidated under AS 21. \\
\hline
\end{tabular}

Ind AS 110 Consolidated Financial Statements

\begin{tabular}{|c|c|c|c|}
\hline SN & Basis of Differences & $\begin{array}{l}\text { Ind AS 110: Consolidated } \\
\text { Financial Statements }\end{array}$ & $\begin{array}{l}\text { AS } 21 \text { Consolidated } \\
\text { Financial Statements }\end{array}$ \\
\hline 1 & Scope & $\begin{array}{l}\text { Mandates the preparation of CFS for a } \\
\text { Parent }\end{array}$ & Not mandatory for a parent. \\
\hline 2 & Control & $\begin{array}{l}\text { Principle based: Investor controls } \\
\text { investee when it is exposed or has } \\
\text { rights to variable returns from } \\
\text { involvement with investee and has } \\
\text { ability to affect those returns through } \\
\text { its power over } \\
\text { investee. }\end{array}$ & $\begin{array}{l}\text { Rule based: } \\
\text { Ownership of more than half } \\
\text { voting power. } \\
\text { Control of composition of board }\end{array}$ \\
\hline 3 & Potential Voting Rights & $\begin{array}{l}\text { Needs to be considered for control } \\
\text { assessment. }\end{array}$ & $\begin{array}{l}\text { Are not considered for control } \\
\text { assessment. }\end{array}$ \\
\hline 4 & Uniform Accounting Policies & $\begin{array}{l}\text { To be followed and no recognition of } \\
\text { situation of impracticability }\end{array}$ & $\begin{array}{l}\text { If not considered for control } \\
\text { assessment. }\end{array}$ \\
\hline 5 & $\begin{array}{l}\text { Notes to consolidated } \\
\text { financial statements }\end{array}$ & No such clarification & $\begin{array}{l}\text { Notes necessary for true \& fair } \\
\text { view and notes involving } \\
\text { material items }\end{array}$ \\
\hline 6 & $\begin{array}{l}\text { Exclusion of subsidiary } \\
\text { from consolidation }\end{array}$ & All subsidiaries are consolidated & $\begin{array}{l}\text { If subsidiary acquired with intention } \\
\text { to dispose of within } \\
12 \text { months or it operates under } \\
\text { severe long term restrictions which } \\
\text { impair its ability to transfer funds to } \\
\text { parent, then subsidiaries } \\
\text { need not be consolidated. }\end{array}$ \\
\hline 7 & $\begin{array}{l}\text { Treatment in case of more than } \\
\text { one parent of a } \\
\text { subsidiary }\end{array}$ & $\begin{array}{l}\text { Each investor would account for its } \\
\text { interest in the investee in accordance } \\
\text { with relevant Ind AS. } \\
\text { Such as Ind AS } 111,28,109\end{array}$ & $\begin{array}{l}\text { Both need to consolidate the } \\
\text { financial statement of that } \\
\text { entity as per AS } 21 \text {. }\end{array}$ \\
\hline 8 & Difference in Reporting Dates & Should not be more than 3 months & Should not be more than 6 months \\
\hline 9 & $\begin{array}{l}\text { Presentation of minority } \\
\text { interest }\end{array}$ & $\begin{array}{l}\text { Should present within equity, } \\
\text { separately from the equity of the } \\
\text { owners of the parent }\end{array}$ & $\begin{array}{l}\text { Presented separately from } \\
\text { liabilities \& equity of the } \\
\text { parent's shareholder. }\end{array}$ \\
\hline
\end{tabular}


International Journal of Trend in Scientific Research and Development (IJTSRD) @ www.ijtsrd.com eISSN: 2456-6470

\section{Reference:}

[1] AICPA (2018b). SEC Road Map for Tramsition to IFRS available. Retrieved from Journal of Accountancy: www.journalofaccountancy.com/web/roadmapfor transitiontoifrsavailable.

[2] Barth, M., Landsman, W. and Lang, M. 2018, „International Accounting Standards and Accounting Quality“, Journal of Accounting Research, 46:467-498.

[3] Daske, H., Hail, L., Leuz, C. and Verdi, R. 2008, „Mandatory IFRS Reporting Around the World: Early Evidence on the Economic Consequences", Journal of Accounting Research, 46(5): 1085-142.

[4] Deloitte (July2018) IFRSs and USGAAP: A pocket comparison. Retrieved from the CPA Journal:www.nysscpa.org/printversions.

[5] Deloitte. 2009, First Time Adoption of International Financial Reporting Standards: A Guide to IFRS 1. Retrieved 5 October 2012 from: http://www.iasplus.com/dttpubs/Ernest \& Young Thinking IFRS? EY Guide on Transition to IFRS

[6] Goodwin, J. and Ahmed, K. 2006, „,The Impact of International Financial Reporting Standards: Does Size Matter Managerial Auditing Journal, 21:460-475.

[7] Goodwin, J., Ahmed, K. and Heaney, R. 2007, „, The Effects of International Financial Reporting Standards on the Accounts and Accounting Quality of Australian Firms: A Retrospective Study", Working Paper, and the Hong Kong Polytechnic University.

[8] Hung, M. and Subramanyam, K. 2010, „Financial Statements Effects of Adopting International Accounting Standards: The Case of Germany", Review of Accounting Studies, 12(4):623-657.

[9] Kenneth Smith 2009 A Cost Benefit Analysis of the Transition from GAAP to IFRS in the United States.

[10] Li, S. 2010, „Does Mandatory Adoption of International Financial Reporting Standards in the European Union Reduce the Cost of Equity Capital? “, the Accounting Review, 85:607-636. Stent, W., Bradbury, M. and Hooks, J. 2010, „IFRS in New Zealand: Effects on Financial Statements and Ratios", Pacific Accounting Review, 22(2):92-107.

[11] Swamynathan Shobhana, Dr. Sindhu(2011) Financial Statement Effects On Convergence to IFRS- A Case Study in India, Zenith International Journal of Multidisciplinary Research, Vol.1 Issue 7 November. Pp 317-336

[12] The Institute of Chartered Accountants of India, Concept Paper on Convergence with IFRS in India

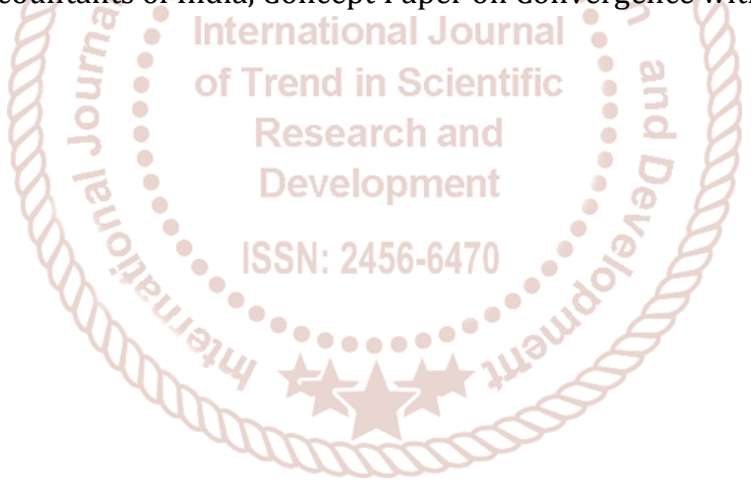

